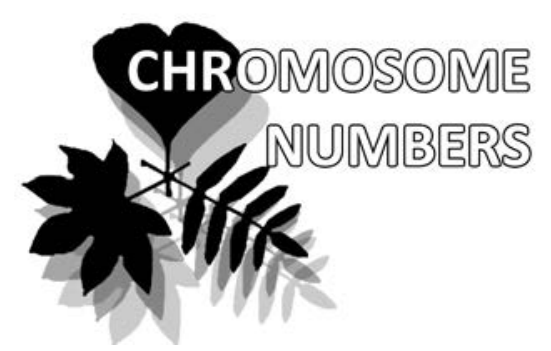

\title{
Chromosome numbers for 12 species of Artemisia (Asteraceae) from the Altai region, West Siberia, Russia
}

\author{
Alexandr A. Korobkov ${ }^{1 *}$, Violetta V. Kotseruba ${ }^{1} \&$ \\ Nina S. Probatova ${ }^{2 *}$
}

Alexandr A. Korobkov ${ }^{1 *}$

e-mail: stereodon@yandex.ru

Violetta V. Kotseruba ${ }^{1}$

e-mail: viola.kotseruba@gmail.com

Nina S. Probatova ${ }^{2}$

e-mail: probatova@ibss.dvo.ru

${ }^{1}$ V.L. Komarov Botanical Institute RAS, Saint-Petersburg, Russia

${ }^{2}$ Federal Scientific Center of the East Asia Terrestrial Biodiversity FEB RAS, Vladivostok, Russia

* corresponding author

Manuscript received: 17.04 .2018 Review completed: 24.04.2018

Accepted for publication: 08.05.2018

Published online: 12.05 .2018

\begin{abstract}
A B S T R A C T
Chromosome numbers (CN) for 12 species of Artemisia L. (Asteraceae) from the Altai region of the West Siberia (Republic of Altai and Altaiskii Krai) are reported. New CNs, previously unknown for the species, were revealed in $A$. latifolia Ledeb. $(2 \mathrm{n}=108)$ and $A$. macrantha Ledeb. $(2 \mathrm{n}=54,98)$. For 8 species there are first $\mathrm{CN}$ counts from Altai region. Brief comments on $\mathrm{CNs}$ and information on ecology and distribution of the species studied are given.
\end{abstract}

K e y w o r d s : chromosome numbers, Artemisia, Asteraceae, vascular plants, Altai region, West Siberia, Russia

\section{P E 3 Ю M E}

Коробков А.А., Коцеруба В.В., Пробатова Н.С. Числа хромосом 12 видов рода Artemisia (Asteraceae) с А^тая, Западная Сибирь, Россия. Сообщаются числа хромосом Аля 12 виАов сосудистых растений из А^тайского региона Западной Сибири (Республика А^тай и А^тайский край). Новые, не известные ранее числа хромосом установлены у A. latifolia Ledeb. $(2 \mathrm{n}=108)$ и $A$. macrantha Ledeb. $(2 \mathrm{n}=54,98)$. В А^тайском регионе впервые исследованы 8 видов. Аля рассматриваемых видов даны комментарии по числам хромосом, и краткая информация по экологии и распространению.

Кнючевые скова: числа хромосом, Artemisia, Asteraceae, сосудистые растения, А^тайский регион, Западная Сибирь, Россия
This paper is the final contribution to chromosome number $(\mathrm{CN})$ studies on Artemisia species in the flora of Altai region of Russia (Korobkov et al. 2014a, c). Plants were collected in the following territories of the Republic of Altai: Chemal'skii, Kosh-Agachskii, Mayminskii, Ongudayskii, Ulaganskii, Ust'Koksinskii, and in Altaiskii Krai: Aleyskii, Burlinskii, Khabarskii, Krasnogorskii, Loktevskii, Mikhailovskii, Pospelikhinskii, Rubtsovskii, Tretyakovskii and Zmeinogorskii, as well as near Barnaul city. Some specimens were provided by the colleagues from the South Siberian Botanical Garden of the Altaiskii State University (ALTB). Figure 1 shows the locations of data sampling points within this area.

$\mathrm{CN}$ counts were made on roots of seedlings germinated from achenes in Petri dishes. Squash preparations were obtained by classic method (Abramova 1988). The accuracy of $\mathrm{CN}$ counts was controlled by making several new preparations from the same herbarium specimen. Voucher specimens are deposited in the basic vascular plants collection of Herbarium LE (V.L. Komarov Botanical Institute, SaintPetersburg), some specimens are in Barnaul city (ALTB).

The symbol (!) before the species name means the first report of $\mathrm{CN}$ for the species from the Altai region. Plants were determined and $\mathrm{CNs}$ commented by A.A. Korobkov. $\mathrm{CN}$ counting was made by V.V. Kotseruba, English translation - by N.S. Probatova.

\section{(!) Artemisia absinthium L., 2n = 18}

Russia, Altaiskii Krai, Pospelikhinskii Raion, the floodplain of the Aley River, near Krasnoyarskoe settlement, the abandoned field along the forest edge, 1 Oct 1999, Korobkov 99-147: 22 (LE); Russia, Altaiskii Krai, Tretyakovskii Raion, N shore of the Gilevskoe water-storage basin, near Korotaikha settlement, along the margin of the tree-planting, forb meadow, 1 Oct 1999, Korobkov 99-148: 24; Russia, Altaiskii Krai, the territory of Barnaul city, Yuzhnyi settlement, the Barnaul'skaya forest dacha, Pinus + Betula belt forest, on riverside, 12 Oct 2009, Korobkov 10-21: 20 (LE).

Distribution: Eurasia - N America. Steppe and foreststeppe species. In the Altai region it occurs in floodplain forests, among shrubs, in the bottoms and slopes of ravines, in meadows at the edges of deciduous forests and tree-plantings, near habitations and on roadsides.

A. absinthium has diploid CN $2 \mathrm{n}=18(\mathrm{x}=9)$ within the whole present area of the species distribution, in the natural and adventive groups of plants (Murin 1997, Kreischitz \& Valles 2003, Korobkov \& Kotseruba 2015). However in Poland one adult plant and 3 seedlings with tetraploid CN 2n $=36$ in population of diploid plants were found (Kreischitz \& Valles 2003).

\section{(!) Artemisia arenaria DC., $2 \mathrm{n}=36$}

Russia, Altaiskii Krai, Loktevskii Raion, in vicinity of Noven'koe settlement, on the shores of saline lake, solitary plants on the slopes of high sandy hills, 2 Oct 1999, Korobkov 99-108: 25 (LE). 
Distribution: SE Europe - S Siberia. The desert and steppe species. In European Russia and in Kazakhstan it occurs on sandy hillocks in the river valleys, on sand dunes and inter-dune depressions in broad sandy massifs, on broken and waved sand slopes of ridges. In Altaiskii Krai A. arenaria was found in the most typical ecotope - in the lake depression, on the non-matted slopes of high sandy hills. The tetraploid $\mathrm{CN} 2 \mathrm{n}=36$ was already known for A. arenaria from Kazakhstan (Filatova 1971) and from European Russia (Korobkov \& Kotseruba 2015). Two very close species to $A$. arenaria from Kazakhstan $-A$. albicerata Krasch. and $A$. quinqueloba Trautv. are tetraploids as well (Filatova 1971, 1977). Diploid CN 2n $=18$ for $A$. arenaria from China (Qiao et al. 1990) probably must be referred to some other species from series Psammophillae Pojark., because the typical $A$. arenaria was not reported for the flora of China (Ling Y.R. 1991).

\section{(!) Artemisia austriaca Jacquem., 2n = 16}

Russia, Altaiskii Krai, Aleyskii Raion, the highway Barnaul - Aleysk, $30 \mathrm{~km} \mathrm{NE}$ of Aleysk town, the valley of a stream, forb-grass steppe meadow, 30 Sep 1999, Korobkov 99-164, 99-218, 99-221: 21 (LE).

\section{$-2 \mathrm{n}=36$}

Russia, Altaiskii Krai, Zmeinogorskii Raion, the lakeside of Kolyvanovskoe Lake, in vicinity of Zmeinogorsk town, the stony-rubbly bar on the slope of a ridge, 1 Oct 1999, Korobkov 99-161: 23 (LE); Russia, Altaiskii Krai, Rubtsovskii Raion, the shore of bitter-saline lake at the border of Kazakhstan, forb-grass meadow along the edge of the treeplantings, 3 Oct 1999, Korobkov 99-162: 26 (LE); Russia, Altaiskii Krai, Burlinskii Raion, the salt lake Bol'shoe Topol'noe, $\mathrm{S}$ sandy lakeside, forb + Artemisia plant community, 6 Oct 1999, Korobkov 99-163: 28 (LE); Russia, Altaiskii Krai, Khabarskii Raion, near Khabary settlement, birch forest, forb + Artemisia plant community at the forest edge, 6 Oct 1999, Korobkov 99-165: 29 (LE); Russia, Altaiskii Krai, Loktevskii Raion, in vicinity of Noven'koe settlement, sandy hillocks along the shore of the salt lake, grass $+A r$ temisia sparse plant community, 2 Oct 1999, Korobkov 99166: 25 (LE).

Distribution: Eurasia. The desert and steppe species, it widely spread in steppe regions of Altaiskii Krai. A. austriaca grows in abundance in steppe meadows, in forb-grass commuities along the tree plantings, in light birch forests, abandoned fields, pastures and near habitations.

A. austriaca shows significant variability of $\mathrm{CNs}$ on population and individual levels. The species is a representative of the plant groups which are able to active vegetative propagation and to formation of large diversity of chromosome races (Pellicer et al. 2007). The CNs $2 \mathrm{n}=16(\mathrm{x}=8)$ and $2 \mathrm{n}=36(\mathrm{x}=9)$ have been already known from $\mathrm{S}$ and E Europe (Kuzmanov et al. 1986, Ferakova 1997, Garcia et al. 2004) as well as from European Russia (Korobkov \& Kotseruba 2015).

\section{Artemisia dracunculus L., 2n $=18$}

Russia, Republic of Altai, Kosh-Agachskii Raion, right riverside of the Chuya River, near Chegan-Uzun settlement, on the slope of the valley, 22 Sep 1999, Korobkov 99-117: 7 (LE).

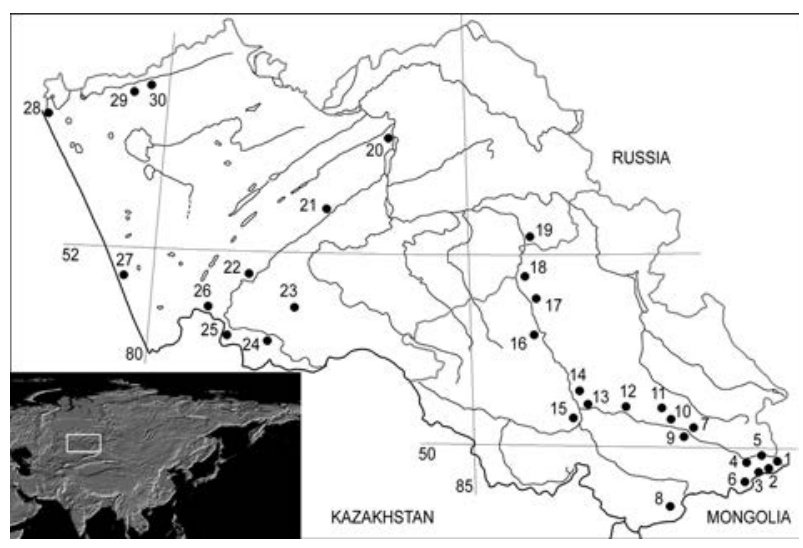

Figure 1 Study area. Dots with numbers from 1 to 30 are the sampling plot locations (according to numbering in the text)

\section{$-2 n=36$}

Russia, Republic of Altai, Ongudaiskii Raion, right riverside of the Chuya River, near the mouth, in the dish between rubbly hillocks, 25 Sep 1999, Korobkov 99-116: 13 (LE); Russia, Republic of Altai, Ulaganskii Raion, near Chibit settlement, on the slope of a stream valley, $21 \mathrm{Sep}$ 1999, Korobkov 99-121: 12 (LE); Russia, Republic of Altai, Chemal'skii Raion, left riverside of the Katun' River, near the bridge, $20 \mathrm{~km} \mathrm{E}$ of Edigen settlement, high terrace, forb steppe with Caragana, 3 Oct 2009, Korobkov 10-37: 26 (LE); Russia, Republic of Altai, Ust'Koksinskii Raion, left riverside of the Koksu River, near the confluence with the Argut River, light Larix forest, at sawmill, 28 Aug 2010, Gnutikov 11-16:15 (LE); Russia, Republic of Altai, KoshAgachskii Raion, in vicinity of Kokorya settlement, S slope of Bashtu Mt., on the scree, 17 Aug 2010, Gnutikov 1119: 4 (LE); Russia, Altaiskii Krai, Burlinskii Raion, the main sandy lakeside of the lake Bol'shoe Topol'noe, Artemisia community on the edge of shrubs, 6 Oct 1999, Korobkov 99-118: 28 (LE); Russia, Altaiskii Krai, Mikhailovskii Raion, in vicinity of Nevodnoe settlement, the main lakeside of Gornostaevo Lake, grass-forb community, 4 Oct 1999, Korobkov 99-119: 27 (LE); Russia, Altaiskii Krai, Tretyakovskii Raion, $\mathrm{N}$ shore of the Gilevskoe water-storage basin, near Korotaikha settlement, flat slope, along the edge of trees planting, 1 Oct 1999, Korobkov 99-120: 24 (LE).

\section{$-2 n=54$}

Russia, Altaiskii Krai, the territory of Barnaul city, Yuzhnyi settlement, the edge of Pinus belt forest, roadside, 19 Sep 1999, Korobkov 99-115: 20 (LE); Russia, Altaiskii Krai, Aleyskii Raion, the highway Barnaul - Aleysk, $30 \mathrm{~km}$ NE of Aleysk town, the valley of a stream, meadow, 30 Sep 1999, Korobkov 99-211: 21 (LE).

\section{$-2 \mathrm{n}=45,54$}

Russia, Altaiskii Krai, the territory of Barnaul city, forb community at the edge of Pinus forest, 10 Oct 2009, Korobkov 10-36: 20 (LE).

Distribution: Eurasia - N America. Steppe and forest-steppe species. In the Republic of Altai and Altaiskii Krai $A$. dracunculus occurs in steppes and saline meadows, in grass-forb communities at the edges of steppe shrubs 
and tree-plantings, in light Betula forests, on the slopes of ravines, at the edge of Pinus forests, in abandoned fields and near habitation. In the native populations of $A$. dracunculus the whole series of $\mathrm{CNs}$ was revealed: from diploids $(2 \mathrm{n}$ $=2 \mathrm{x}=18)$ till decaploids $(2 \mathrm{n}=10 \mathrm{x}=90)$ (Agapova et al. 1990, Shokhina et al. 2001, Kreischitz \& Valles 2003). Our $\mathrm{CN}$ count $2 \mathrm{n}=18$ from the valley of Chuya River agree with earlier data (Krasnikov 1985, Shokhina et al. 2001) on the presence of diploid race in Gornyi Altai. Polyploid races of $A$. dracunculus are widely distributed in steppe and forest-steppe plains of Altaiskii Krai. Near Barnaul city we revealed aneuploidy $(2 \mathrm{n}=45,54)$ in $A$. dracunculus: it was already known from Poland (Kreischitz \& Valles 2003), as well as in Orenburgskaya Oblast', S Urals (Korobkov \& Kotseruba 2015).

\section{Artemisia glabella Kar. et Kir., 2n $=18$}

Russia, Altaiskii Krai, the territory of Barnaul city, South Siberian Botanical Garden, introduction plot, 17 Sep 1999, Korobkov 99-130: 20 (LE).

Distribution: E Kazakhstan. Steppe rocky species. This $\mathrm{CN} 2 \mathrm{n}=18$ was revealed on plants from collection of $\mathrm{S}$ Siberian Botanical Garden in Barnaul. The origin of plants studied: Kazakhstan, Karagandinskaya Oblast', near Taldy village (Kuprijanov 1995). The polyploid CN in A. glabella was already known from the officinal plants collection in Karaganda (Probatova et al. 2010). All the species close to A. glabella from Siberia and Kazakhstan are diploids: $A$. altaiensis Krasch., A. filatovae Kupr., A. martjanovii Krasch. et Poljakov, A. obtusiloba Ledeb., A. subviscosa Turcz. ex Besser.

\section{(!) Artemisia latifolia Ledeb., 2n $=\mathbf{5 4}$}

Russia, Altaiskii Krai, the territory of Barnaul city, near Yuzhnyi settlement, the Barnaul'skaya forest dacha, Pinus + Betula belt forest, grass-forb meadow on the slope of narrow valley, 19 Sep 1999, Korobkov 99-184: 20 (LE).

\section{$-2 n=72$}

Russia, Altaiskii Krai, the territory of Barnaul city, in vicinity of Yuzhnyi settlement, the Barnaul'skaya forest dacha, Pinus + Betula belt forest, grass-forb meadow on the slope of depression, 19 Sep 1999, Korobkov 99-185, 99186: 20 (LE).

\section{$-2 n=108$}

Russia, Altaiskii Krai, the territory of Barnaul city, near Yuzhnyi settlement, the Barnaul'skaya forest dacha, Pinus + Betula belt forest, on the slope of depression, forb meadow, 11 Sep 2009, Korobkov 10-10: 20 (LE).

Distribution: E Europe - S Siberia. The steppe and forest-steppe species. In Altaiskii Krai A. latifolia occurs in grass-forb meadows in Pinus forest edges and in light birch forests, among shrubs on the ravine slopes, in meadow steppes. Hexaploid CN 2n $=6 \mathrm{x}=54$ was already known for A. latifolia in Omskaya Oblast', in Orenburgskaya Oblast' as well as in Tyva Republic (Samojlova 1990, Korobkov et al 2013, Korobkov \& Kotseruba 2015). The octoploid CN $2 \mathrm{n}=8 \mathrm{x}=72$ has been revealed in A. latifolia from Tomskaya Oblast' (Malakhova \& Markova 1994). The tetraploid $\mathrm{CN} 2 \mathrm{n}=4 \mathrm{x}=36$ was reported for this species from Jenissey area, but without exact indication of the plant origin (Amel'chenko 1979). Aneuploid CN - 2n = 108 is reported here for the first time.

\section{(!) Artemisia macrantha Ledeb., $2 \mathrm{n}=54$}

Russia, Republic of Altai, Ulaganskii Raion, SW foothills of the Kurai mountain ridge, $10 \mathrm{~km} \mathrm{~N}$ of Kurai settlement, S slope of a hill, forb-grass meadow at the edge of Larix forest, 23 Sep 1999, Korobkov 99-197, 99-198: 11 (LE); Russia, Altaiskii Krai, the territory of Barnaul city, in vicinity of Yuzhnyi settlement, the Barnaul'skaya forest dacha, Pinus + Betula belt forest, forb meadow on the slope of small depression, 19 Sep 1999, Korobkov 99- 199: 20 (LE).

\section{$-2 \mathrm{n}=98$}

Russia, Altaiskii Krai, the territory of Barnaul city, near Yuzhnyi settlement, the Barnaul'skaya forest dacha, Pinus + Betula forest belts, grass-forb meadow among sparse birch trees, 17 Sep 1999, Korobkov 99-213: 20 (LE).

Distribution: E Europe - E Siberia. The forest and forest-steppe species. On the plains of Altai region $A$. macrantha can be found in grass-forb meadows at the edges and in glades of the pine and deciduous forests, among shrubs on ravine slopes, in steppe meadows; as to mountain areas the species occurs at the upper limit of deciduous forests, in forb meadows. A. macrantha demonstrates the considerable karyological polymorphism. The diploid $(2 \mathrm{n}=18)$ and tetraploid $(2 \mathrm{n}=36) \mathrm{CNs}$ have been revealed in Omskaya Oblast' (Samojlova 1999). Polyploid races in A. macrantha are known from Tomskaya Oblast' $(2 \mathrm{n}=108)$ and Central Yakutia $(2 \mathrm{n}=$ c.100) (Malakhova 1990, Probatova et al. 2010). Hexaploid CN 2n $=54$, as well as aneuploid CN 2n $=98$, we revealed in $A$. macrantha for the first time.

\section{(!) Artemisia obtusiloba Ledeb., 2n = 36}

Russia, Republic of Altai, Kosh-Agachskii Raion, near the pass Sozontu, 21 Aug 1998, Shmakov \& German 9942: 2 (ALTB); Russia, Republic of Altai, Kosh-Agachskii Raion, the valley of Ulandryk River, near the outcome from the mountains, 22 Aug 1998, Shmakov \& German 99-43, 99-44: 6 (ALTB); Russia, Republic of Altai, Ulaganskii Raion, right riverside of the Chuya River near the mouth, the second floodplain terrace, 25 Sep 1999, Korobkov 99128: 13 (LE); Russia, Republic of Altai, Ongudayskii Raion, right riverside of the Katun' River, near Inya settlement, the bottom of stony slope of a hill, 21 Sep 1999, Korobkov 99-129: 14 (LE).

Distribution: S Siberia-Mongolia. The mountainsteppe species. In Mountain Altai $A$. obtusiloba occurs on stony slopes in forb-meadow steppes and Artemisia + Caragana communities, on granite rocks, on screes, matted sands. The $\mathrm{CN}$ in A. obtusiloba $(2 \mathrm{n}=36)$ has been counted in Tyva Republic (Korobkov et al. 2013). In Altai region the $\mathrm{CN}$ for this species is revealed first time.

\section{Artemisia rupestris L., 2n $=18$}

Russia, Altaiskii Krai, Mikhailovskii Raion, in vicinity of Nevodnoe settlement, the shore of saline lake Gornostaevo, the ditch at the margin of Pinus forest, grass-forb plant community, 4 Oct 1999, Korobkov 99-138: 27 (LE); Russia, Altaiskii Krai, Khabarskii Raion, near Khabary settlement, stony slope to the lake, 6 Oct 1999, Korobkov 99-139: 29 (LE); Russia, Altaiskii Krai, Aleyskii Raion, the highway Barnaul - Aleysk, $30 \mathrm{~km} \mathrm{NE}$ of Aleysk town, the valley of a stream, forb-grass meadow steppe, 30 Sep 1999, Korobkov 99-140: 21 (LE). 
Distribution: Eurasia - N America. The forest-steppe species. In flat forest-steppe territories of Altaiskii Krai A. rupestris occurs in forb-sagebrush-grass steppes on solonetz, in floodplain forests, in light Larix forests, pine forests, on alkaline lands, pastures and abandoned fields. The diploid CN $2 \mathrm{n}=18(\mathrm{x}=9)$ is known for $A$. rupestris from Europe and from Siberia (Ehrenorfer 1964, Samojlova 1999). The aneuploid $\mathrm{CN} 2 \mathrm{n}=16$ for $A$. rupestris from Yenissey area (Amel'chenko 1979) still remains unconfirmed. The report of CN 2n $=18$ from Republic of Altai, Kosh-Agachskii Raion (Krasnikov 1965) must be referred to $A$. viridis Willd., which is widely distributed in altitudes of the Altai highlands. To A. viridis probably belongs the polyploid $\mathrm{CN}$ from Altai, but the plants were misidentified as A. rupestris (Sokolovskaya \& Strelkova 1948).

(!) Artemisia sacrorum Ledeb. (= A. gmelinii auct. non Weber ex Stechm.; A. jawajomogy Kitam.), 2n = 54

Russia, Republic of Altai, Mayminskii Raion, the valley of Katun' River, near Ust'-Muny settlement, the bottom of W rubbly slope of a hill, 29 Sep 1999, Korobkov 99-182: 18 (LE); Russia, Altaiskii Krai, Krasnogorskii Raion, the right slope of the valley of Katun' River, at the border with Republic of Altai, W slope of a terrace, the sagebrush-shrubs community, 27 Sep 1999, Korobkov 99-181: 19 (LE); Russia, Altaiskii Krai, Khabarskii Raion, in vicinity of Ust'Kurja settlement, the way slope, grass-forb community, 6 Oct 1999, Korobkov 99-183: 30 (LE).

\section{$-2 \mathrm{n}=36,45,54$}

Russia, Republic of Altai, Chemal'skii Raion, the valley of the Katun' River, near Chemal settlement, riverside rock outcrops, 3 Oct 2009, Korobkov 10-25: 17 (LE); Russia, Republic of Altai, Chemal'skii Raion, left riverside of the Katun' River, near the bridge, $20 \mathrm{~km}$ E of Edigen settlement, high terrace, forb steppe with Caragana, 4 Oct 2009, Korobkov 10-24, 10-27:16 (LE); Russia, Altaiskii Krai, the territory of Barnaul city, near Yuzhnyi settlement, the edge of the Pinus belt forest, shrub-forb plant community,10 Oct 2009, Korobkov 10-28: 20 (LE).

Distribution: Asia. The steppe, forest-steppe species. In Altai region it occurs in the river valleys on riverside rocks and stony alluvial deposits, among shrubs on the ravine slopes, on high terraces in sagebrush-grass communities, on forest edges and on margins of pine forests. The hexaploid $\mathrm{CN} 2 \mathrm{n}=54$ is constant in $A$. sacrorum all along the continental part of its area of distribution, from Altai till the Sea of Okhotsk coast, including Primorskii Krai (where 2n $=54$ - see Probatova 2014), as well as in Sakhalin and Hokkaido. The tetraploid race $(2 \mathrm{n}=36)$ exists in the natural populations in China (Yan et al., 1989) and as to Russia - in Republic of Khakassia (Probatova et al. 2010). There is a report (probably, an error) of $2 \mathrm{n}=18$, from "Vladivostok" (Hoshi et al. 2003). Mixoploid races with 2n $=52-54$ are known from Hokkaido, Japan (Suzuka, 1950), and $2 \mathrm{n}=45,54-$ in Russia, from Yenissei area in Krasnoyarskii Krai (Amel'chenko 1979).

\section{Artemisia sericea Weber ex Stechm., 2n $=72$}

Russia, Republic of Altai, Ulaganskii Raion, right riverside of the Chuya River near Chibit settlement, hilly terrace, flat slope of depression, grass-forb meadow at the edge of shrubs community, 21 Sep 1999, Korobkov 99167: 12 (LE); Russia, Republic of Altai, Ulaganskii Raion, right riverside of the Chuya River, the bottom of abrupt SE slope of a hill, forb-shrubs plant community along the edge of Larix forest, 21 Sep 1999, Korobkov 99-219: 12 (LE); Russia, Altaiskii Krai, Tretyakovskii Raion, $\mathrm{N}$ shore of the Gilevskoe water-storage basin, near Korotaikha settlement, in shrubs along the margin of trees-planting, 1 Oct 1999, Korobkov 99-220: 24 (LE)

Distribution: Eurasia. The steppe and foreststeppe species. In the Republic of Altai A. sericea is present in grass-forb steppes on high terraces of the river valleys, in shrubs growing on the slopes of depressions, in meadows at the edges and skirts of the mountain larch forests. In steppe and forest-steppe areas of Altaiskii Krai $A$. sericea occurs in meadows with steppe elements, in grass-forb meadows along the margins of pine forests, on shrubby slopes of ravines, in light birch groves. The octoploid CN 2n $=72$ was already known in $A$. sericea from natural populations in European Russia and Transbaikalia (Korobkov et al. 2014b, Korobkov \& Kotseruba 2015). All along its geographical area, $A$. sericea demonstrates the high variability of polyploid CNs. The diploid CN 2n $=18$, counted on Moscow material (Kawatani \& Ohno 1964), was not confirmed by nobody else. Tetraploid plants of this species were collected near Krasnoyarsk city (Stepanov 1994).

\section{Artemisia viridis Willd., $2 \mathrm{n}=18$}

Russia, Republic of Altai, Kosh-Agachskii Raion, eastern extremity of Severo-Chuyskii mountain range, $5 \mathrm{~km}$ NW of Chegan-Uzun settlement, 23 Aug 1998, Shmakov, German \& Antonjuk 99-46: 9 (ALTB); Russia, Republic of Altai, Kosh-Agachskii Raion, near Boguty Lake, 20 Aug 1998, Shmakov, German \& Antonjuk 99-47: 3 (ALTB); Russia, Republic of Altai, Ulaganskii Raion, right riverside of the Chuya River near Chibit settlement, hilly terrace, on the slope of shallow depression, grass-forb steppe, 21 Sep 1999, Korobkov 99-135, 99-137: 12 (LE); Russia, Republic of Altai, Ulaganskii Raion, right riverside of the Chuya River near Kurai settlement, S slope of a hill, grass-forb upland steppe, 23 Sep 1999, Korobkov 99-136: 10 (LE); Russia, Republic of Altai, KoshAgachskii Raion, the plateau Ukok, $2255 \mathrm{~m}$ alt., on the shore of small lake, 28 Aug 2011, Gnutikov 2013-54, 2013-56, 2013-57: 8 (LE); Russia, Republic of Altai, KoshAgachskii Raion, $2476 \mathrm{~m}$ alt., on the shore of Naryn-Gol Lake, 18 Aug 2011, Gnutikov 2013-59: 1 (LE); Russia, Republic of Altai, Kosh-Agachskii Raion, $2000 \mathrm{~m}$ alt., the riverside of Bar-Burgazy River, slopes with steppe vegetation, 16 Aug 2011, Gnutikov 2013-60: 5 (LE); Russia, Republic of Altai, Kosh-Agachskii Raion, the lakeside of Naryn-Gol Lake, $2762 \mathrm{~m}$ alt., upper part of a canyon, slide-rocks, 20 Aug 2011, Gnutikov 2013-64: 1 (LE).

Distribution: S Siberia - Central and Middle Asia. The mountain steppe and rocky species. On uplands of the Altai Republic it occurs in grass-forb mountain steppes in the river valleys and lake depressions, on the slopes, on pebbles and rubbly placer. The diploid $\mathrm{CN} 2 \mathrm{n}=18$ was already known from Kyrgyzstan (Chuksanova et al. 1968, Probatova et al. 2010) and from Altai (see Annotation to A. ruprestris). 


\section{CONCLUSION}

Flora of the Altai Region includes 46 species of Artemisia. Before the $\mathrm{CNs}$ were studied from Altai in $A$. dracunculus, $A$. rupestris, A. gmelinii Weber ex Stechm. and $A$. macrocephala Jacquem. ex Besser (Sokolovskaya \& Strelkova 1948, Krasnikov 1985, Krasnikov \& Shirina 2006). Now the CNs are known in 39 species of Artemisia from Russian Altai. From among, 19 species are represented by diploids ( $2 \mathrm{n}$ $=2 \mathrm{x}=18, \mathrm{x}=9 ; 2 \mathrm{n}=2 \mathrm{x}=16, \mathrm{x}=8)$; they comprise 8 mountain species (A. macrocephala, A. viridis, A. caespitosa Ledeb., A. compacta Fischer ex DC., $A$. dolosa Krasch., A. leucophylla (Turcz. ex Besser) Pamp., A. rutifolia Steph. ex Spreng., A. schischkinii Krasch.) and 9 steppe and foreststeppe species (A. absinthium, A. abrotanum L., A. gracilescens Krasch. \& Iljin, A. laciniata Willd., A. pauciflora Weber ex Stechm., A. pontica L., A. ruprestis, A. scoparia Waldst. et Kit., A. sublessingiana Krasch. ex Poljakov), as well as two ruderal weeds $-A$. sieversiana Ehrh. ex Willd. and $A$. vulgaris $\mathrm{L}$. The tetraploid $\mathrm{CN}(2 \mathrm{n}=4 \mathrm{x}=36, \mathrm{x}=9)$ was revealed in steppe species (A. arenaria, A. commutata Besser, A. marschalliana Spreng., $A$. schrenkiana Ledeb.) and in mountain species A. obtusiloba. As to $A$. altaiensis, $A$. argyrophylla Ledeb. and A. tanacetifolia L., they are hexaploids $(2 \mathrm{n}=6 \mathrm{x}=54, \mathrm{x}=$ 9). The octoploid $\mathrm{CN}(2 \mathrm{n}=8 \mathrm{x}=72, \mathrm{x}=9)$ was found in A. sericea in mountain and lowland populations. Several species show combinations of cytotypes, such as $A$. austriaca, A. gmelinii, A. frigida Willd., A. glauca Pall. ex Willd., A. phaeolepis Krasch., each of them has di- and tetraploid cytotypes. A. nitrosa Weber ex Stechm., in addition to $2 \mathrm{x}$ and $4 \mathrm{x}$, has mixoploid cells $(2 \mathrm{n}=34,36)$. In mountain populations of A. depauperata Krasch. the diploid, triploid and tetraploid cytotypes occur. $A$. dracunculus has diploid, tetraploid and hexaploid cytotypes, as well as mixoploid with $2 \mathrm{n}=45,54$. In mountain and lowland populations of $A$. sacrorum the hexaploid CN $(2 \mathrm{n}=54)$ is common, but in the valley of the Katun' River and in the suburbs of Barnaul city mixoploids were revealed $(2 \mathrm{n}=36,45,54)$. On the small territory of the pine forest belt near Barnaul city the $3 \mathrm{CNs}$ were found in A. latifolia: $2 \mathrm{n}=54,72,108$. In mountain plants of A.macrantha $2 \mathrm{n}=54$ was revealed, while on forest edges and margins of pine forest near Barnaul the $2 \mathrm{n}=54$ and $2 \mathrm{n}=108$ were found. The $\mathrm{CNs}$ of $A$. armeniaca Lam., $A$. annua L., A. bargusinensis Spreng., A multicaulis Ledeb., A. palustris L., A. pycnorbiza Ledeb. and $A$. salsoloides Willd. are not studied yet in Altai Region, where they are rare species.

\section{ACKNOWLEDGEMENTS}

The authors are grateful to colleagues from the South Siberian Botanical Garden of the Altaisky State University for their help in the fieldwork, and to Alexandr A. Gnutikov (V.L. Komarov Botanical Institute RAS) for providing plant material from Republic of Altai.

The study was financially supported by the Russian Foundation for Basic Research (grant 160400052, to A.A. Korobkov).

\section{LITERATURE CITED}

Abramova, L.I. 1988. Determination of chromosome numbers and description of its morphology in the meristem and pollen grains of cultivated plants. Methodical instructions. Leningrad. 64 pp. (in Russian). [Абрамова А.И. 1988. Определение числа хромосом и описание их морфологии в меристеме и пыльцевых зернах культурных растений. Методические указания. $\Lambda .64$ с.].

Agapova, N.D., K.B. Arkharova, L.I. Vakhtina, E.A. Zemskova \& L.V. Tarvis 1990. Chromosome numbers in flowering plants of the flora of the USSR: Asteraceae - Menyanthaceae. Nauka, Leningrad. 509 pp. (in Russian). [Агапова H.A., Архарова А.Б., Вахтина А.И., Земскова Е.А., Тарвис А.В. 1990. Числа хромосом цветковых растений флоры СССР: семейства Asteraceae - Menyanthaceae. А.: Наука. 509 с.].

Amel'chenko, V.P. 1979. Contribution to study of Artemisia from Yenisei group. In: New data on the Siberian nature, pp. 114-118 (in Russian). [Амельченко В.П. 1979. К изучению полыней Приенисейской группы / / Новые данные о природе Сибири. Томск. С. 114-118.].

Chuksanova, N.A., L.I. Sveshnikova, T.V. Aleksandrova 1968. New data on chromosome numbers in species of Compositae. Cytologia 10(3):382-386 (in Russian). [Чуксанова Н.А., Свешникова А.И., Александрова Т.В. 1968. Новые Аанные о числах хромосом у видов семейства сложноцветных // Цитология. Т. 10, № 3. С. 382386].

Ehrendorfer, F. 1964. Notizen zur Cytotaxonomie und Evolution der Gattung Artemisia. Österreichische botanische Zeitschrift 111(1):84-142.

Feráková, V. 1997. Artemisia austriaca - druh kriticky karyotaxonomickeho hladiska. Preslia 69:95-113.

Filatova, N.S. 1971. De Caryotipis specierum Artemisii subgenere Dracunculus (Bess.) Rydb. Botanicheskie materialy Gerbaria Instituta botaniki AN KazSSR 7:46-49 (in Russian). [Филатова Н.С. 1971. Кариотипы песчаных видов полыней подрода Dracunculus (Bess.) Rydb. // Ботан. Материалы Гербария Ин-та ботан. АН КазССР. Вып. 7. C. 46-49].

Filatova, N.S. 1977. Analysis Geographica specierum endemicarum Artemisiae in Kazachstania crescentium. Botanicheskie materialy Gerbaria Instituta botaniki AN Kaz SSR 10:58-69 (in Russian). [Филатова Н.С. 1977. Географический анализ эндемичных видов полыней Казахстана // Ботан. Материалы Гербария Ин-та ботан. АН КазССР. Вып. 10. С. 58-69].

Garcia, S., M. Sanz, T. Garnatje, A. Kreitschitz, E. Durant, E.D. McArthur \& J. Valles. 2004. Variation of DNA amount in 47 populations of the subtribe Artemisiinae and related taxa (Asteraceae, Anthemideae): karyological, ecological and systematic implications. Genome 47:1004 1014.

Hoshi, Y., K. Kondo, A.A. Korobkov, I.V. Tatarenko, P.V. Kulikov, V.P. Verkholat, A. Gontcharov, H. Ogura, T. Funamoto, G. Kokubugata, R. Suzuki \& H. Matoba 2003. Cytological study in the genus Artemisia L. (Asteraceae) from Russia. Chromosome Science 7:83-89.

Kawatani, T. \& T. Ohno 1964. Chromosome numbers in Artemisia. Bulletin of National Institute of Hygienic Sciences 82: 183-193.

Korobkov, A.A. \& V.V. Kotseruba 2015. Chromosome numbers of some species of Artemisia (Asteraceae) of European Russia. Botanicheskii Zhurnal 100(11):11891217 (in Russian). [Коробков А.А. Коцеруба В.В. 2015. Числа хромосом некоторых видов рода Artemisia (Asteraceae) Европейской России // Ботанический журнац. Т. 100, № 11. С. 1189-1217].

Korobkov, A.A., V.V. Kotseruba \& N.S. Probatova 2014a. Chromosome numbers of some species of Artemisia L. 
from Altai region, South Siberia. Botanica Pacifica 3(1):6166.

Korobkov, A.A., V.V. Kotseruba \& V.V. Chepinoga 2014b. IAPT/IOPB chromosome data 17 (K. Marhold \& I. Breitwieser, eds). Taxon 63(5):1151-1152, E 12-18.

Korobkov, A.A., V.V. Kotseruba, N.S. Probatova \& A.V. Shatokhina 2014 c. IAPT / IOPB chromosome data 18 (K. Marhold, ed.). Taxon 63(6):2-4.

Krasnikov, A.A. 1985. Numbers of chromosome of some Asteraceae species from Siberia. Botanicheskii Zhurnal 70(12):1702-1703 (in Russian). [Красников А.А. 1985. Числа хромосом некоторых представителей семейства Asteraceae из Сибири // Ботанический журнал. T. 70, № 12. C. 1702-1703].

Krasnikov, A.A. \& E.P. Shirina 2006. Chromosome numbers of some Artemisia species (Asteraceae) from Siberia. Botanicheskii Zhurnal 91(3):481-482 (in Russian). [Kpacников А.А., Ширина Е.П. 2006. Хромосомные числа некоторых видов Artemisia (Asteraceae) из Сибири // Ботанический журнал. Т. 91, № 3. С. 481-482].

Kreitschitz, F. \& J. Valles 2003. New or rare data on chromosome numbers in several taxa of the genus Artemisia (Asteraceae) in Poland. Folia Geobotanica 38(3):333-343.

Kupriyanov, A.N. 1995. Initial stages of ontomorphogenesis of Artemisia glabella Kar. et Kir. in the south of Siberia In: Flora and vegetation of Altav: Proceedings of South Siberian Botanical Garden, pp. 127-130. Barnaul (in Russian). ККуприянов А.Н. 1995. Начацьные этапы онтоморфогенеза Artemisia glabella Kar. et Kir. в условиях юга Сибири // ФАора и растительность Алтая: Труды Южно-Сибирского ботанического сада. Барнаул. С. 127-130].

Kuzmanov, B.A., S.B. Georgieva \& V.A. Nikolaeva 1986. Chromosome numbers in Bulgarian flowering plants. 1. Asteraceae. Fitologia 31:71-75 (in Bulgarian). [Кузманов Б.А., Георгиева С.Б., Николаева В.А. 1986. Хромозомни числа на бъемгарски цветни растения. 1. Asteraceae // Фитология 31:71-75].

Ling, Y.R. 1991. Angiospermae. In: Flora Republicae popularis Sinicae (Ling Y. \& Ling Y.R., eds), vol. 76(2), 321 pp. Agendae Academia Sinicae, Pekin (in Chinese).

Malakhova, L.A. 1990. Caryological analysis of nature populations of rare and endangered plants in the south of 'Tomsk Region. Byulleten' Glavnogo Botanicheskogo Sada 155:60-66 (in Russian). [Малахова А.А. 1990. Кариомогический анализ природных популяций реАких и исчезающих растений на юге Томской области // Бюмлетень ГАавного ботанического сада. Вып. 155. C. 60-66].

Malakhova, L.A. \& G.A. Markova 1994. Chromosome numbers of flowering plants of the Tomskaya Oblast'. Dicotyledons. Botanicheskii Zhurnal 79(12):103-106 (in Russian). [Малахова А.А., Маркова Г.А. 1994. Числа хромосом цветковых растений Томской области. Авудольные //
Ботанический журнал. Т. 79, № 12. С. 103-106].

Murin, A. 1997. Karyotaxonomy of some medicinal and aromatic plants. Thaiszia Journal of Botany 7:75-88.

Pellicer, I., S. Garnatje, T. Garnatje, Sh. Darrimaa, A.A. Korobkov \& J. Valles 2007. Chromosome numbers in some Artemisia (Asteraceae, Anthemideae) species and genome size variation in subgenus Dracunculus: karyological, systematic and phylogenetic implications. Chromosome Botany 2:45-53.

Probatova, N.S. 2014. Chromosome numbers in vascular plants of the Primorskii Krai (Russian Far East). Dal'nauka, Vladivostok. 343 pp. (in Russian). [Проб̆атова Н.C. 2014. Хромосомные числа сосудистых растений Приморского края (АаАьний Восток России). ВАаАивосток: Аальнаука. 343 с.].

Probatova, N.S., A.A. Korobkov, A.A. Gnutikov, E.G. Rudyka, V.V. Kotseruba \& V.P. Seledets 2010. IAPT / IOPB chromosome data 10 (K. Marhold, ed.). Taxon 59(6): 1935-1937, E 6-10.

Qiao, Y.M., X.X. Yan \& S.Z. Zhang 1990. A study of the chromosomes of 20 species Artemisia. Grassland of China 6: 24-31.

Samojlova, G.V. 1999. Sages of the Omskaya Oblast' (geography, ecology, chemosystematics, chromosome numbers). Author's abstr. of PhD dissert. Novosibirsk. 16 pp. (in Russian). [Самоймова Г.В. 1999. Полыни Омской области (география, экология, хемосистематика, хромосомные числа). Автореф. Аисс. .... канА. биол. наук Новосибирск. 16 с.].

Sokolovskaya, A.P. \& O.S. Strelkova 1948. Geographical distribution of polyploids. II. The study of the flora of Altai. Uchenye zapiski gosudarstvennogo pedagogicheskogo instituta imeni A.I. Gertsena 66(8):179-193 (in Russian). [Соколовская А.П., Стрелкова О.С. 1948. Географическое распределение полиплоилов. II. Исследование фморы Алтая // Ученые зап. гос. пед. ин-та им. А.И. Герцена. Т. 66. Вып. 8. С. 179-193].

Stepanov, N.V. 1994. Chromosome numbers of some higher plants taxa of the flora of Krasnoyarsk Region. Botanicheskii Zhurnal 79(2):135-139 (in Russian). [Степанов Н.В. 1994. Числа хромосом некоторых таксонов высших растений Красноярского края // Ботанический журнал. Т. 79, № 2. С. 135-139].

Suzuka, O. 1950. Chromosome numbers in the genus Artemisia. Japanese Journal of Genetics 25:17-18.

Shokhina, N.K., I.B. Rutskikh \& A.P. Dolgikh 2001. Biology of some polyploid races of Artemisia dracunculus (Asteraceae). Botanicheskii Zhurnal 86(12):60-72 (in Russian). Шохина Н.К., Руцких И.Б., Аолгих А.П. 2001. Биомогия полиплоилных рас Artemisia dracunculus (Asteraceае) // Ботанический журнац. Т. 86, № 12. С. 60-72].

Yan, X.X., S.Z. Zhang, J.F. Yan, X.Q. Fu \& L.Y. Wang 1989. Chromosome numbers and geographical distribution of 68 species of forage plants. Grassland of China 4:53-60. 